\title{
PELLON ARVOSTA LIPERIN KUNNASSA VUOSINA 1956-1960
}

\author{
VILJO RYYNÄNEN \\ Helsingin yliopiston maanviljelystalouden laitos
}

Saapunut 13. 11. 1961

Liperin kunta sijaitsee Pohjois-Karjalan läänissä $0-45$ km Joensuun kaupungin rajasta länteen. Pitäjän halki kulkee Joensuu-Pieksämäki rautatie ja JoensuuOutokumpu-Kuopio maantie sekä Joensuu_Liperi-Savonlinna maantie. Liperin pitäjään kuuluu runsaasti vesistöjä. Sen kokonaispinta-alasta on noin $30 \%$ veden peittämää. Suurimpia järviä ovat Pyhäselkä, Orivesi ja Viinijärvi. Monien järvien ja lampien sekä vaihtelevan maastonsa vuoksi pitäjä on suurelta osalta luonnonkaunista seutua.

Peltoa on noin $16 \%$ koko maa-alasta. Hieta ja hiesusavi ovat yleisimmät peltojen maalajit. Turvemaita on vähän. MäKI (5) on tutkimuksessaan todennut, että Liperin pitäjän pelloista on noin $80 \%$ täysin kivettömiä ja vain $7 \%$ hyvin kivisiä. Peltoalueet ovat lähellä vesistöjä ja verrattain yhtenäisiä. Monet suuret lähellä olevat järvet tekevät ilmaston verraten suotuisaksi kasvinviljelylle. Niinpä esimerkiksi hallojen tuhot ovat olleet lieviä ja pitäjän parhaimmilla viljelyalueilla harvinaisia.

Seuraavassa käsitellään kauppahintojen sekä tuotantokustannusten perusteella määritettyä pellon arvoa Liperin kunnassa. Lisäksi verrataan saatuja tuloksia eräisiin muunnetun maatalousmaan kirjanpitoarvoihin.

\section{Pellon arvo kauppahintojen perusteella}

Tutkimusaineisto. Liperin pitäjän Liperin kylän alueelta on koottu vapaaehtoisissa kaupoissa maksettuja maatilojen ja rakentamattomien peltoalueiden hintoja. Sukulaisten keskeisiä kauppoja, pakkomyyntejä tai näihin verrattavia ei sisälly aineistoon. Kaupan kohteista maksettu hinta on saatu kaupanvahvistajan päiväkirjasta. Myös pinta-aloja koskevat tiedot on alustavasti otettu samasta asiakirjasta, mutta ne on tarkistettu veroluokituskortistosta ja -kartoilta, joista asiakirjoista on saatu myös maatalousmaan pistearvot ja verohehtaarin määrät. Liperin 
kunnassa on vuonna 1955 otettu käytäntöön uusi veroluokitus, joten sekä pintaalat että maatalousmaan suhteellinen hyvyys ovat melkoisella luotettavuudella tiedossa.

Jokaiseen myytyyn maatilaan tai rakentamattomaan alueeseen on kirjoittaja käynyt henkilökohtaisesti tutustumassa, arvioinut samalla rakennukset ja tarkkaillut metsän puustoa sekä niitä seikkoja, jotka huomattavimmalla tavalla vaikuttavat objektin arvoon, mutta joita ei ole huomioitu veroluokituksessa.

Tutkimusaineistoon kuuluu 18 kauppaa. Pienellä yhtenäisellä maatalousalueella ja lyhyen ajanjakson aikana tapahtuu niukasti maatilojen ja peltoalueiden kauppoja. Jos ajanjaksoa olisi pidennetty, olisi inflatio vaikuttanut jo merkittävällä tavalla tulokseen. Maatilakauppoja on kyllä Liperin kylän alueella mainittuna ajanjaksona tehty monta kertaa enemmän kuin tutkimukseen mukaan otetut tapaukset, mutta varsin huomattava osa niistä oli sukulaisten välisiä kauppoja. Useaan vieraiden henkilöiden keskiseen kauppaan sisältyi sellaisia rasitteita (eläke, oikeus pelloista saatuun tuotokseen tai oikeus viljellä osaa pelloista myyjän kuolemaan saakka ym.), joiden arviointi yksityistapauksissa on vaikeaa. Eräissä kaupoissa oli taas metsää niin paljon, että varsinaisen maatalouden osuus kauppahinnasta olisi ollut hyvin vaikea erottaa.

Kaupan kohteena olleista maatiloista ja rakentamattomista peltoalueista kuului 13 kirkonkylän viljelyalueeseen, joka ulottuu $3-5 \mathrm{~km}$ säteellä kirkonkylän keskustasta. Kirkonkylä ympäristöineen on sekä ilmastonsa että maalajiensa puolesta pitäjän suotuisinta maatalousaluetta. Loput viisi kaupan kohdetta sijaitsivat 6-12 km kirkonkylästä olevalla viljelyalueella, jolle on tyypillistä edellisestä selvästi karumpi maaperä, hieman hajanaisempi asutus ja pienempi viljelmäkoko. Vallitsevana maalajina tällä alueella on karkea hieta, kun taas kirkonkylä ympäristöineen on suurelta osalta hiesusavea.

Viljelykunto myydyillä maatiloilla oli heikko. Tähän lienee vaikuttanut entisten omistajien vähäiset mahdollisuudet harjoittaa maanviljelyä. Kolme entisistä omistajista ilmoitti, etteivät he vanhuuden vuoksi enää jaksaneet hoitaa maatilaansa, kaksi oli sairauden, yksi alaikäisyyden vuoksi holhouksen alla. Yhden myydyistä maatiloista omisti perikunta, jonka osakkaista kukaan ei ollut halukas sitä viljelemään.

Myydyt lisäalueet olivat tilussuhteiltaan hyviä. Yhdeksästä lisäalueesta viisi sijaitsi lähempänä kuin $0.5 \mathrm{~km}$ talouskeskuksesta, johon ne liitettiin, kolmen etäisyys oli $0.5-1.0 \mathrm{~km}$ ja yhden noin $7 \mathrm{~km}$. Lisäalueet sijaitsivat kolmea lukuunottamatta hyvän maantien varrella. Peltokuviot olivat säännöllisiä suorakaiteen muotoisia eikä niillä esiintynyt mainittavasti kiviä. Lisäalueiden viljelykunto oli keskinkertainen tai sitä parempi. Lisäalueista 5 oli samasta maatilasta, jonka omistaja ei ollut halukas jatkamaan maanviljelyä, kolme oli myyty siksi, että ne sijaitsivat liian kaukana talouskeskuksesta ja kolme sen vuoksi, että omistaja oli saanut ne perintönä, mutta ei katsonut asialliseksi ryhtyä rakentamatonta aluetta viljelemään.

Tilussuhteet on arvioitu asteikon $1-3$ mukaan, jossa 1 on heikko, 2 tyydyttävä ja 3 hyvä. Ympäristö on arvioitu niinikään asteikolla $1-3$, jossa 1 on heikoin. Ympäristötekijään on luettu luonnonkauneus sekä pihan piirissä koristepuiden, 
Taulukko 1. Kaupan kohteena olleiden maatilojen ja rakentamattomien peltoalueiden eräitä ominaisuuksia.

Table 1. Certain properties of the farms and unbuilt field areas involved in the transaction.

\begin{tabular}{|c|c|c|c|c|c|c|c|c|c|c|c|}
\hline \multirow[b]{2}{*}{$\begin{array}{l}\begin{array}{c}\text { Tilan } \\
\text { No }\end{array} \\
\text { No. of } \\
\text { farm }\end{array}$} & \multicolumn{3}{|c|}{$\begin{array}{c}\text { Maankäyttölajit } \\
\text { Land utilization types }\end{array}$} & \multicolumn{6}{|c|}{$\begin{array}{c}\text { Etäisyys km } \\
\text { Distance }(\mathrm{km}) \text { from }\end{array}$} & \multirow[b]{2}{*}{ 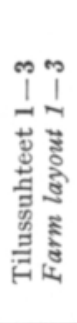 } & \multirow[b]{2}{*}{ 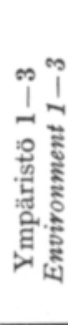 } \\
\hline & $\begin{array}{l}\text { Maatalous- } \\
\text { maata } \\
\text { vero-ha } \\
\text { Agricultural } \\
\text { land, tax-ha }\end{array}$ & 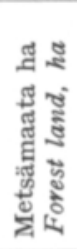 & 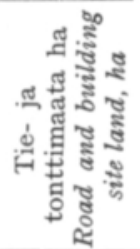 & 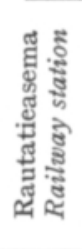 & 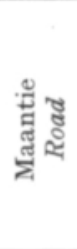 & 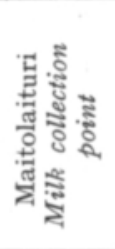 & 总沾 & 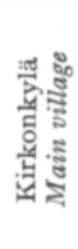 & 点 & & \\
\hline
\end{tabular}

$\begin{array}{rrrrrrrrrrrr}1 & 6.60 & - & - & 18 & 0.2 & - & 4.0 & 4 & 0.3 & 2 & 1 \\ 2 & 7.64 & 24.81 & 0.38 & 7 & 0.4 & 0.4 & 2.5 & 8 & 5 & 1.5 & 1 \\ 3 & 17.76 & 31.78 & 0.50 & 24 & 2.0 & 0.6 & 2.5 & 8 & 3 & 2 & 1 \\ 4 & 2.40 & - & - & 19 & 0.4 & - & 1.0 & 4 & 1 & 2 & 1 \\ 5 & 3.60 & - & - & 19 & 0.3 & - & 1.0 & 4 & 0.4 & 3 & 2 \\ 6 & 6.96 & - & - & 18 & 0.2 & - & 2.0 & 3.5 & 0.3 & 3 & 3 \\ 7 & 12.00 & - & - & 17 & 0.2 & - & 2.5 & 3 & 0.2 & 3 & 3 \\ 8 & 11.24 & - & - & 17 & 0.2 & - & 2.0 & 2.5 & 0.4 & 3 & 3 \\ 9 & 12.32 & 58.17 & 0.33 & 5 & 0.1 & 0.1 & 1.0 & 9 & 5 & 1.5 & 1 \\ 10 & 7.08 & - & 0.05 & 10 & 0.6 & - & 2.0 & 4 & 0.3 & 1.5 & 2 \\ 11 & 3.83 & 3.50 & - & 11 & 0.3 & - & 3.0 & 3 & 0.7 & 2 & 1 \\ 12 & 3.30 & - & - & 4 & 0.5 & - & 2.0 & 10 & 4 & 2 & 1 \\ 13 & 9.90 & 22.44 & 0.71 & 4 & 0.7 & 0.7 & 1.5 & 10 & 2.5 & 1.5 & 1 \\ 14 & 5.81 & 9.79 & 0.30 & 11 & 0.2 & 0.1 & 3.5 & 3 & 0.2 & 2 & 3 \\ 15 & 42.87 & - & 1.00 & 12 & 0.1 & 0.1 & 3.0 & 3 & 0.3 & 3 & 3 \\ 16 & 10.20 & 12.43 & 0.20 & 16 & 1.0 & 1.0 & 1.3 & 5 & 4 & 1.5 & 1 \\ 17 & 7.43 & 3.92 & - & 18 & 0.3 & - & 1.0 & 1 & 0.6 & 2 & 2 \\ 18 & 0.48 & - & - & 4 & 1.0 & - & 2.0 & 10 & 4 & 2 & 2 \\ \text { Keskim. } & & & & & & & & & & & \end{array}$

pensaiden, kukkien, nurmikoiden ja rakennusten keskinäisen sijoittelun avulla saatu viihtyisyys. Tarkemmat tiedot tilussuhteista ja eräistä muista seikoista on esitetty taulukossa 1. Niittyjä ja laitumia kuului kaupan kohteena olleisiin maatiloihin $7.9 \%$ verohehtaareitten kokonaismäärästä. Suhteellisesti eniten näitä oli tiloilla $9,11,15,17$ ja 18 . Niityt ja laitumet olivat hyvätuottoisia ja niitä käytettiin nautakarjan ja hevosten laitumina.

\section{Maatalousmaan muntaminen verohehtaareiksi}

Peltomaa on ilmoitettu verohehtaareina, joiden määrä on laskettu kuten maatalouskiinteistöjen verojyvityksestä ja luokituksesta annetuissa ohjeissa (10) esitetään. Näiden mukaan muuntaminen tapahtuu siten, että tiluskuvion hehtaareina laskettu pinta-ala kerrotaan verojyvityksessä sille annetun pistearvon sadasosalla. Siis yksi hehtaari 100 pisteen arvoista peltoa on yksi verohehtaari. Luonnon- 
niitylle annettua pistearvoa on ensin alennettava $50 \%$ :lla ja luonnonlaitumelle annettua pistearvoa $70 \%: l l a$, minkä jälkeen niiden pinta-alat muunnetaan verohehtaareiksi.

Ilmoittamalla peltoala verohehtaareina saadaan yhtenäinen perusta eri maatilojen ja rakentamattomien alueiden hinnan vertaamiseksi keskenään. Esim. maatila A:n kaupassa myydään 10.00 ha 1 luokan (esim. 130 pisteen) peltoa, joka maksaa $120000 \mathrm{mk} / \mathrm{ha}$, ja maatila B:n kaupassa 10.00 ha III luokan (esim. 70 pisteen) peltoa joka maksaa $85000 \mathrm{mk} / \mathrm{h}$. Laskemalla pelto verohehtaareiksi saadaan A:lle 13.00 ja B:lle 7.00 verohehtaaria. Verohehtaarin hinta tapauksessa A olisi $92300 \mathrm{mk}$ ja tapauksessa B $114300 \mathrm{mk}$. Ellei muuntamista verohehtaareiksi suoritettaisi, olisi vertailu vaikeaa. Kun uudessa veroluokituksessa on pyritty pellon (tai luonnonniityn ja laitumen) pistearvojen perusteella ilmaisemaan kunkin peltokuvion tuottokyky, voidaan pistearvoja ajatella käytettäväksi myös verrattaessa eri peltokuvioitten tai lähellä olevien eri maatilojen peltojen arvoja toisiinsa.

Käytettäessä paikkakunnan keskimääräistä pellon hintaa esim. pakkolunastustapauksissa korvauksia maksettaessa on sangen kohtuullista, että pellon hyvyys otetaan huomioon. Tällöin rakentamattomasta pellosta maksettavaa korvausta voitaisiin ajatella muutettavaksi samassa suhteessa kuin pellon pistearvo muuttuu.

Myyty, rakentamaton peltoalue on saattanut sijaita entiseen talouskeskukseen nähden hyvin epäedullisesti ja saada tästä johtuen veroluokituksessa runsaasti miinuspisteitä. Jos myytävä pelto kuitenkin sijaitsee ympäristöönsä nähden niin, että se voidaan muihin maatiloihin liittää lisämaaksi ilman maninittua etäisyyshaittaa, on etäisyydestä annetut miinuspisteet jätetty huomioon ottamatta.

\section{Kauppahinnan jakaminen eri omaisuusryhmien kesken}

Seitsemään tutkittuun kauppaan kuului pelkkää peltoa ja yhteen sekä peltoa että luonnonniittyä. Kun luonnonniitty tässä yhteydessä on ilmoitettu verohehtaareina, saadaan yllä esitetyissä tapauksissa verohehtaarin hinta suoraan jakamalla kauppahinta verohehtaareitten luvulla.

Kymmeneen kauppaan kuului pellon, luonnoniityn ja laitumen lisäksi metsää ja rakennuksia. Kun näissäkin tapauksissa oli pyrkimyksenä saada selville, mitä pellosta maksettiin, oli kauppahinta jaettava eri omaisuusryhmien kesken. Jako on suoritettu siten, että kukin omaisuusryhmä on arvioitu erikseen myöhemmin esitettävällä tavalla. Arviot on laskettu yhteen ja kauppahinta jaettu omaisuusryhmien arvojen summalla. Näin saadulla osamäärällä on sitten kerrottu pellon, rakennusten ja metsän arvioitu arvo. Tulo osoittaa, mikä osa kauppahinnasta kuuluu kullekin omaisuusryhmälle.

Maatalousmaa on arvioitu ottamalla II luokan pellon arvoksi $100000 \mathrm{mk}$. Tämä on valittu paikkakunnalla vallitsevan käsityksen perusteella, jonka mukaan keskinkertaisen paljaan pellon arvo olisi noin $100000 \mathrm{mk} / \mathrm{ha}$. Ensimmäisen luokan pellon arvoa on korotettu $30 \%$ :lla ja kolmannen luokan pellon arvoa vastaavasti alennettu $30 \%:$ :lla. Niityn arvoksi on otettu keskimäärin $50 \%$ pellon arvosta ja laitumen arvoksi $30 \%$ pellon arvosta. 
Rakennuksille on arvioitu niiden nykyarvo laskemalla rakennusten kuutiotilavuus ja kertomalla saatu kuutiomäärä ohjehinnoilla ottaen samalla huomioon rakennusten poikkeavuus AROLAn (2) esittämästä "normaalirakennuksesta" sekä kulumisesta aiheutunut arvon aleneminen. Kuutiohintana on käytetty ARoLAn e.m. kirjoituksessa antamia ohjehintoja, joihin on tehty rakennuskustannusindeksin mukainen korjaus (10\%). Rakennukset olivat yhtä asuinrakennusta lukuunottamatta $30-100$ vuotta vanhoja.

Metsät tutkituilla maatiloilla kuuluivat pääasiassa toiseen luokkaan. Puusto oli vähäinen. Puuston muodosti heikkolaatuinen koivu ja leppä. Kuusta ja mäntyä oli hyvin niukasti. Kun myytyjen tilojen metsät kuuluvat suurelta osalta vanhaan kaskialueeseen, jota myöhemmin on laidunnettu, on niille kehittynyt varsin yhtenäinen lehtipuuvaltainen puusto. Metsän arvoksi on otettu kunkin maatilan metsän verotusarvo. Vain maatilan n:o 14 metsän arvoa on korotettu verotusarvon yläpuolelle sen kohtalaisen runsaan puuston ansiosta. Kunkin maatilan maatalousmaan rakennusten ja metsän arvioitu arvo, kauppahinta ja kauppahinnan ja arvioidun arvon suhde esitetään taulukossa 2 .

Taulukko 2. Kaupan kohteena olleiden maatilojen ja rakentamattomien peltoalueiden arvioitu arvo, kauppahinta ja verohehtaarin hinta.

Table 2. The appraised value of farms and unbuilt field areas involved in the transaction, sale price and price per tax-hectare.

\begin{tabular}{|c|c|c|c|c|c|c|c|c|}
\hline \multirow{2}{*}{$\begin{array}{l}\text { Tilan } \\
\text { No } \\
\text { No. of } \\
\text { farm }\end{array}$} & \multicolumn{4}{|c|}{$\begin{array}{c}\text { Arvioitu arvo } 1000 \mathrm{mk} \\
\text { Appraised value, } 1000 \text { marks }\end{array}$} & \multirow{2}{*}{$\begin{array}{l}\text { Kauppa- } \\
\text { hinta } \\
1000 \mathrm{mk} \\
\text { Sale price } \\
1000 \text { marks }\end{array}$} & \multirow{2}{*}{$\begin{array}{c}\text { Kauppahin- } \\
\text { nan suhde } \\
\text { arvioituun } \\
\text { arvoon } \\
\text { Ratio sale } \\
\text { price to } \\
\text { appraised } \\
\text { value }\end{array}$} & \multirow{2}{*}{$\begin{array}{c}\text { Veroha:n } \\
\text { hinta } \\
1000 \mathrm{mk} \\
\text { Price of tax- } \\
\text { hectare, } \\
1000 \text { marks }\end{array}$} & \multirow{2}{*}{$\begin{array}{c}\text { Veroha:n } \\
\text { hinta } \\
\text { raken- } \\
\text { nuksineen } \\
1000 \mathrm{mk} \\
\text { Price of tax- } \\
\text { hectare } \\
\text { with buildings } \\
1000 \text { marks }\end{array}$} \\
\hline & 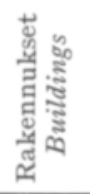 & 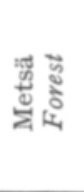 & 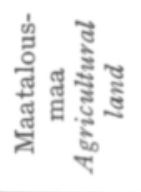 & 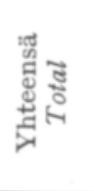 & & & & \\
\hline 1 & - & - & - & - & 1100 & - & 162 & - \\
\hline 2 & 1250 & 507 & 777 & 2534 & 2400 & 0.947 & 96 & 252 \\
\hline 3 & 2700 & 720 & 1706 & 5126 & 3700 & 0.722 & 69 & 182 \\
\hline 4 & - & - & - & - & 360 & - & 150 & - \\
\hline 5 & - & - & - & - & 600 & - & 166 & - \\
\hline 6 & - & - & - & - & 1000 & - & 144 & - \\
\hline 7 & - & - & - & - & 1700 & - & 142 & - \\
\hline 8 & - & - & - & - & 1800 & - & 160 & - \\
\hline 9 & 1190 & 1333 & 1230 & 3753 & 4000 & 1.066 & 128 & 209 \\
\hline 10 & 50 & - & 665 & 715 & 817 & 1.143 & 108 & - \\
\hline 11 & - & 90 & 383 & 473 & 390 & 0.825 & 82 & - \\
\hline 12 & - & - & - & - & 300 & - & 91 & - \\
\hline 13 & 1310 & 435 & 990 & 2735 & 2500 & 0.914 & 92 & 213 \\
\hline 14 & 260 & 650 & 589 & 1499 & 1800 & 1.201 & 122 & 177 \\
\hline 15 & 4715 & - & 4276 & 8991 & 6600 & 0.734 & 73 & 154 \\
\hline 16 & 605 & 235 & 1023 & 1863 & 1500 & 0.805 & 81 & 129 \\
\hline 17 & - & 90 & 752 & 842 & 1700 & 2.019 & 207 & - \\
\hline 18 & - & - & - & - & 65 & - & 135 & - \\
\hline
\end{tabular}




\section{Pellon hinta rakennuksineen}

Pellon hinta rakennuksineen on laskettu verohehtaaria kohden. Tulokset on esitetty erikseen asuin- ja talousrakennuksin varustettua ja vain talousrakennuksin varustettua verohehtaaria kohden. Tulokset käyvät ilmi taulukosta 3. Vertailun vuoksi on taulukkoon otettu a.o. maatilojen verotusarvot vuoden 1960 verotuksen mukaan sekä Sisä-Suomen kirjanpitotilojen 1 ja II tilasuuruusluokan vastaavat arvot muunnettua peltohehtaaria kohden kirjanpitovuonna 1958/59 (9).

Taulukko 3. Verohehtaarin arvo tutkimuksen ja verotuksen mukaan Liperin pitäjässä sekä muunnetun peltoha:n arvo kirjanpitoarvion mukaan Sisä-Suomessa.

Table 3. The value of the tax-hectare in the commune of Liperi according to the investigation and to taxation assessment, and the value of the converted field hectare according to book-keeping estrmates in Central Finland.

Arvioimismenetelmä Method of valuation

\section{Verohehtaarin arvo $1000 \mathrm{mk}$ \\ Value of tax-hectare, 1000 marks}

\begin{tabular}{|c|c|c|c|c|}
\hline \multicolumn{3}{|c|}{$\begin{array}{l}\text { Koko maatilat } \\
\text { The farm as a whole }\end{array}$} & \multirow{2}{*}{$\begin{array}{c}\text { Rakenta- } \\
\text { mattomat } \\
\text { peltoalueet } \\
\text { Unbuilt } \\
\text { field areas }\end{array}$} & \multirow{2}{*}{$\begin{array}{l}\text { Keskimää- } \\
\text { räinen vero- } \\
\text { hehtaarin } \\
\text { arvo ilman } \\
\text { rakennuksia } \\
\text { Average value } \\
\text { of field hectare } \\
\text { excluding } \\
\text { buildings }\end{array}$} \\
\hline $\begin{array}{c}\text { Rakennettu } \\
\text { verohehtaari } \\
\text { Built-up } \\
\text { field hectare }\end{array}$ & $\begin{array}{c}\text { Vero- } \\
\text { hehtaari } \\
\text { talousraken- } \\
\text { nuksineen } \\
\text { Field hectare } \\
\text { with farm } \\
\text { buildings }\end{array}$ & $\begin{array}{c}\text { Vero- } \\
\text { hehtaari } \\
\text { ilman raken- } \\
\text { nuksia } \\
\text { Field hectare } \\
\text { excluding } \\
\text { buildings }\end{array}$ & & \\
\hline
\end{tabular}

\begin{tabular}{lccccc}
\hline $\begin{array}{l}\text { Kauppa-arvo } \\
\text { Sale price }\end{array}$ & 173 & 134 & 83 & 147 & 119 \\
$\begin{array}{l}\text { Verotusarvo } \\
\text { Taxable value }\end{array}$ & 66 & - & 23 & - & - \\
Kirjanpitoarvo $^{1} \mathrm{I} I \mathrm{lk}-$ Class I & 300 & 198 & 58 & - & - \\
Book-keeping value II $\mathrm{lk}-$ Class II & 220 & 155 & 57 & - & - \\
\hline
\end{tabular}

\footnotetext{
${ }^{1}$ Muunnettu peltohehtaari

Converted field hectare
}

Kauppa-arvion mukaan rakennetun peltohehtaarin arvo oli $162 \%$ korkeampi kuin verotusarvion mukaan. LARSSONin (4) suorittama tutkimus osoittaa, että Kalmarin ja Östergotlandin lääneissä Ruotsissa vuosina 1947-1949 rakennetun peltohehtaarin kauppa-arvo oli $79 \%$ korkeampi kuin verotusarvo. Meillä vastaavia tutkimuksia ei liene suoritettu. Kun tämän tutkimuksen aineisto on pieni, ei sen perusteella saatua tulosta voida yleistää. Sitä paitsi tutkituilla maatiloilla rakennukset olivat niin vanhoja, ettei niiden osoittama rakennusten arvo peltohehtaaria kohden vastaa rakennusten keskiarvoa kaikilla maatiloilla. Kaupan kohteena olleilla maatiloilla oli peltoa, niittyä ja laidunta keskimäärin 15.21 verohehtaaria eli suunnilleen sama määrä kuin II tilasuuruusluokassa oli Sisä-Suomen kirjanpitotiloilla muunnettua maatalousmaata, jota oli 15.91 ha (9). Näiden kirjanpitotilojen rakennetun peltohehtaarin kirjanpitoarvo oli 1.27 kertaa niin korkea kuin pellon ja raken- 
nusten hinta verohehtaaria kohden tutkituissa kaupoissa. Kauppa-arvion ja kirjanpitoarvion välinen ero saattaisi johtua yksinomaan siitä, että arvioitavat objektit sijaitsevat eri paikkakunnilla, mutta eroon vaikuttanee myös rakennusomaisuuden alhainen arvo myydyillä maatiloilla. Kun rakennusomaisuuden kirjanpitoarvo oli II:ssa tilasuuruusluokassa 1958/59 $163000 \mathrm{mk}$ muunnettua hehtaaria kohden, oli tutkittujen maatilojen rakennusten arvioitu arvo vain $113000 \mathrm{mk} /$ verohehtaari. Kaupoissa maksetuista maatilojen hinnoista tuli rakennusten osalle keskimäärin $90000 \mathrm{mk} /$ verohehtaari.

Ensimmäisen luokan peltomaa on verotusta varten annettujen ohjeiden mukaan laskettava 1.30 verohehtaariksi. Kertomalla maatilan kauppojen perusteella saatu rakennetun verohehtaarin arvo $173000 \mathrm{mk}$ luvulla 1.30 saadaan rakennetun I luokan peltohehtaarin arvoksi $225000 \mathrm{mk}$.

AALto (1) mainitsee voimajohtoalueiksi lunastetusta I luokan pellosta maksetun Keski-Pohjanmaan karuimmissa pienviljelysvaltaisissa kunnissa $180000 \mathrm{mk} / \mathrm{ha}$, Etelä-Pohjanmaan itäisissä kunnissa $200000 \mathrm{mk} / \mathrm{ha}$ ja eräissä Etelä-Pohjanmaan kunnissa, jotka kuuluvat maakunnan hyviin viljelysseutuihin, $300.000 \mathrm{mk} / \mathrm{ha}$. AALTo ei mainitse esittävätkö hänen mainitsemansa luvut rakennettua vai rakentamatonta peltohehtaaria. Kun korvauksia maksettaessa on ollut tapana, ettei korvata erikseen tyhjäksi jääviä rakennuksia, lienee myös AALLON mainitsemissa tapauksissa kysymyksessä rakennetusta peltohehtaarista maksettu hinta.

Tämän tutkimuksen mukaan rakennetusta I luokan peltohehtaarista on maksettu lähes sama hinta kuin AALLON mainitsemissa tapauksissa. Jos rakennukset olisivat olleet keskinkertaiset, olisi rakennetun pellon hinta ilmeisesti noussut vielä korkeammaksi. Vertailua AALLON mainitsemien maanhintojen kanssa suoritettaessa on otettava huomioon, että ne edustavat »kalleinta käypää hintaa». Laissa kiinteän omaisuuden pakkolunastuksesta 8 §:ssä säädetään, että omistajalle suoritettava korvaus kiinteästä omaisuudesta on määrättävä kiinteistön kalleimman käyvän hinnan mukaan (8). Sen vuoksi vapaaehtoisissa kaupoissa maksettu keskimääräinen maan hinta, kun otetaan lisäksi huomioon, että kaupan kohteet olivat kirjoittajan mukaan paikkakunnan keskitason alapuolella, on alhaisempi kuin pakkolunastustapauksissa maksettava hinta.

Maan hinta eri paikkakunnilla vaihtelee. Virolainen (6, p. 143-144) on tutkimuksessaan merkinnyt maan arvoa 100:lla sen maanviljelysseuran alueella, jolla maan arvo oli korkein. Kahden maanviljelysseuran alueella hän sai maan arvoksi alle $50 \%$ tästä, kuuden maanviljelysseuran alueella $50-70 \%$, seitsemän maanviljelysseuran alueella $70-90 \%$ ja neljän alueella $90-100 \%$. Yhden paikkakunnan hintatilaston perusteella ei voitane päätellä, mikä on maan arvo jollakin toisella, tutkitusta alueesta kaukana olevalla paikkakunnalla. Maan arvoon vaikuttavat niin monet seikat, että kunkin paikkakunnan taso täytynee määritellä erikseen.

Pienillä maatiloilla rakennusten arvo peltohehtaaria kohden on suurempi kuin suurilla. Sisä-Suomen alueen kirjanpitotilojen I suuruusluokassa oli rakennusten arvo vuonna 1958/59 $243000 \mathrm{mk} / \mathrm{ha}$. Jos tämä lisätään tutkimuksessa saatuun I luokan pellon arvoon, tulee ensimmäisen luokan rakennetun pellon arvoksi $7-8$ peltohehtaarin tiloilla $351000 \mathrm{mk}$. Kun suoritetaan rakennetun peltohehtaarin 
vertailuja, olisi välttämätöntä tietää, kuinka suurista maatiloista on kysymys. Rakennetun peltohehtaarin arvo muuttuu oleellisesti tilan koon muuttuessa kuten mm. KoKKonen (3) ja LARSSON (4) ovat osoittaneet.

Vähentämällä asuinrakennuksen osuus rakennetun peltohehtaarin arvosta saadaan talousrakennuksin varustetun peltohehtaarin arvo. Asuinrakennusten osuus kaikkien rakennusten arvosta oli tutkituilla tiloilla $42 \%$. Kirjanpitotiloilla se on viime vuosina ollut $38-45 \%$. Vaihtelu eri tilasuuruusluokkien kesken on ollut vähäinen (9). Talousrakennuksin varustetun verohehtaarin arvoksi tuli tutkimuksen mukaan $134000 \mathrm{mk}$ ja I luokan pellon arvoksi talousrakennuksineen 174000 $\mathrm{mk} / \mathrm{ha}$.

\section{Pellon hinta}

Pellon hinta kokonaisten maatilojen kaupoissa oli keskimäärin $83000 \mathrm{mk} /$ verohehtaari (taulukko 3), joka on 3.61 kertaa niin korkea kuin verotusarvo ja 1.45 kertaa niin korkea kuin muunnetun peltohehtaarin kirjanpitoarvo Sisä-Suomessa kirjanpitovuosina 1958/59. Verohehtaari ja muunnettu peltohehtaari eivät ole kuitenkaan täysin rinnastettavissa, joskaan ero suurehkoa aineistoa tarkasteltaessa ei muodostune suureksi.

Rakentamattomien peltoalueiden kaupoissa on pellosta maksettu $147000 \mathrm{mk}$ verohehtaaria kohden. Pellon hinta näissä kaupoissa on ollut $78 \%$ korkeampi kuin pellon hinta kokonaisten maatilojen kaupoissa. Osan tästä suuresta erosta selittänee se, että lisämaan tarve paikkakunnalla on suuri. Yli 2.00 ha viljelmien keskikoko vuoden 1959 maatalouslaskennan mukaan oli Liperin pitäjässä 8.42 ha peltoa. Kun metsää ja sivuansiotöitä on pitäjässä vähän, on pyrkimys laajentaa peltoalaa voimakas. Pienillä viljelmillä rakennuksia, kalustoa ja työvoimaa ei sanottavasti tarvitse lisätä vaikka peltoa lisätäänkin. Siksi pienen viljelmän omistaja katsoo kannattavaksi toimenpiteeksi ostaa maata lähes rakennetun peltohehtaarin hinnalla. Itseasiassa kysymyksessä onkin rakennetun ja kalustetun pellon osto. Rakennukset ja kalusto on jo aiemmin hankittu viljelmälle ja maan osto suoritetaan jälkikäteen. LARSSON (4) sanoo: "Jos rakennettu maa maksaa $2500 \mathrm{kr} / \mathrm{ha}$ ei pidetä kohtuuttomana maksaa $2000 \mathrm{kr} /$ ha rakentamattomasta lisämaasta». Suoritettu tutkimus osoitti, että lisämaasta oli maksettu $85 \%$ paikkakunnan rakennetun pellon hinnasta.

\section{Viljelmäkoon vaikutus yksikköhintaan}

Alla olevassa asetelmassa esitetään pellosta maksettu hinta kokonaisten maatilojen kaupoissa suhdelukuina. Alle 10.00 verohehtaarin maatiloilla verohehtaarista maksettu keskimääräistä hintaa on merkitty 100:lla. Vertailun vuoksi on viereiseen sarakkeeseen otettu pellon suhteellinen arvo KoкKоSEN (3) tutkimuksen mukaan.

Maan suhteellinen hinta

Tämän tutkimuksen mukaan

KoKKoSEN mukaan

Peltoa vero-hehtaaria Suhdeluku

7.78

100 Peltoa ha Suhdeluku 
Havaintojen luku tässä tutkimuksessa on vähäinen. Sekä käsilläoleva että KоккоSEN tutkimus osoittavat kuitenkin sangen suurta yhdenmukaisuutta.

Rakentamattomien peltoalueiden kaupoissa maksettu hinta verohehtaaria kohden jakaantui seuraavasti:

$\begin{array}{ccc}\text { Peltoa vero-hehtaaria } & \text { Hinta mk } & \text { Suhdeluku } \\ \text { alle } \quad 5.00 & 125000 & 100 \\ 5.00-10.00 & 155000 & 124 \\ \text { yli } 10.00 & 151000 & 121\end{array}$

Tulos on edelliseen verrattuna päinvastainen. Tähän lienee osittain vaikuttanut se, että alle 5.00 hehtaarin alueista, joita oli neljä, kolmelle tieyhteys oli huomattavasti heikompi kuin muille peltoalueille.

\section{Pellon arvo tuotantokustannusten perusteella}

Viljelykelpoisen maan arvo on yleensä alhaisempi kuin pellon arvo. VIRoLAINEN (6) on esittänyt, että viljelykelpoisen maan arvo oli siirtoväen pika-asutuslain toimeenpanon yhteydessä muodostetuilla tiloilla $17 \%$ pellon arvosta. Lisäarvo, jonka viljelykelpoinen alue saa peltona, johtuu suurelta osalta raivauskustannuksista, mutta myös perusviemäri- ja tieverkoston rakentaminen sekä peruslannoitus- ja kalkitus kohottavat sen arvoa.

Pohjois-Karjalan maanviljelysseuran antamien tietojen mukaan pellon raivauskustannukset Liperin pitäjän alueella vuonna 1960 oli arvioitu peltohehtaaria kohden 93000 markaksi. Arvio käsitti 105 ha raivattavaa maata. Jos oletetaan, että peruslannoitukseen on käytetty $4000 \mathrm{~kg}$ kalkkia, $800 \mathrm{~kg}$ hienofosfaattia ja $400 \mathrm{~kg}$ kálisuolaa ja osuus perusviemäri- ja tieverkostosta jätetään kokonaan pois, saadaan peltohehtaarin arvoksi alla olevan laskelman mukaan $137000 \mathrm{mk}$.

Pellon raivauskustannukset

Peruslannoitus ja kalkitus (pyöristetty)

Kalkki $\quad 4000 \times 2: 50 \mathrm{mk}$

Hienofosf. $\quad 800 \times 12: 00 \mathrm{mk}$

Kalisuola $\quad 400 \times 18: 00 \mathrm{mk}$

Viljelyskelpoisen maan arvo $17 \%$ pellosta $^{1}$
$93000 \mathrm{mk}$ 27000 "

$$
\begin{gathered}
10000 \mathrm{mk} \\
9600 \quad \\
7200
\end{gathered}
$$

17000

$137000 \mathrm{mk}$

Viljelykelpoisen maan arvo tulee näin laskien kirjoittajan käsityksen mukaan liian alhaiseksi. Toimiessaan kuuden vuoden aikana Liperin pitäjässä maatalousneuvojana kirjoittaja joutui tekemään noin tuhat pellonraivaussuunnitelmaa. Useissa tapauksissa viljelykelpoinen maa oli ostettu ja sen arvo vaihteli $30000-$ $50000 \mathrm{mk} / \mathrm{ha}$ välillä. Myös raivauskustannukset ha kohden saattavat olla esitettyä suuremmat. Kun raivauspalkkio ei kohoa, laskettiinpa raivauskustannukset kuinka

${ }^{1}$ Keskiluokan pellon arvoksi otettu $100000 \mathrm{mk} / \mathrm{ha}$. 
paljon tahansa yli $70000 \mathrm{mk} / \mathrm{ha}$, esiintyy ilmeisesti tietoista pyrkimystä tehdä vaikeasti raivattavien alueiden kustannusarvio alle todellisten raivauskustannusten.

Peltoteistä ja perusviemäreistä johtuvat kustannukset eivät sisälly pellon raivauskustannuksiin. Kuitenkin nämä aiheuttavat huomattavia kustannuksia ennenkuin peltoa voidaan järkiperäisesti hoitaa. Jos edellä olevaan laskelmaan lisätään noin $20000 \mathrm{mk} / \mathrm{ha}$ tie- ja perusviemärikustannuksiin, päädytään $157000 \mathrm{mk}$ hehtaarihintaan. Tämä on suunnilleen sama kuin edellä esitetty rakentamattomien peltoalueiden kauppojen perusteella laskettu verohehtaarin arvo.

Tämä esimerkki osoittaa vain hyvin karkeasti millaiseksi pellon arvo voisi muodostua, jos perustana käytettäisiin tuotantokustannuksia. Pellon arvo tuotantokustannusten mukaan arvioituna saattaa nousta korkeammaksi kuin rakentamattoman pellon hinta paikkakunnalla. Siitä huolimatta pellon raivaus voi olla yksityistaloudellisesti edullista. Peltoa raivattaessa voidaan näet käyttää viljelmällä olevaa työvoimaa hyväksi juuri silloin, kun viljelmällä ei ole muuta työtä ja tyytyä tällöin raivauskustannuslaskelmissa käytettyä työtunnin hintaa alempaan korvaukseen. Yksityistaloudessa on lisäksi otettava kustannuksia vähentävänä tekijänä huomioon valtion maksama uudisraivauspalkkio. Se on ollut viime vuosina $5.01-10.00$ peltohehtaarin viljelmillä ja raivauskustannusten ollessa edellä mainitun suuruiset $28000 \mathrm{mk} / \mathrm{ha}$ ja $10.01-15.00$ peltohehtaarin viljelmillä $21000 \mathrm{mk} / \mathrm{ha}$. Palkkiota ovat saaneet vain ne, joiden verotettavat tulot ovat olleet alle säädetyn enimmäisrajan ja peltoala raivauksen kanssa alle 15.00 ha $(7)$.

\section{Lоррирӓ̈̈telmät}

Kaupan kohteena olleisiin maatiloihin kuului peltoa ja niittyä 15.21 verohehtaaria. Pellon arvoksi asuin- ja talousrakennuksineen tuli kauppahintojen mukaan $173000 \mathrm{mk}$ verohehtaaria kohden. Pellon arvoksi talousrakennuksineen (ilman asuinrakennusta) tuli $134000 \mathrm{mk} /$ verohehtaari ja paljaan pellon arvoksi 83000 $\mathrm{mk} /$ verohehtaari. Vastaavat arvot laskettuna I luokan peltoa kohden olisivat: $225000 \mathrm{mk} / \mathrm{ha}, 174000 \mathrm{mk} / \mathrm{ha}$ ja $108000 \mathrm{mk} / \mathrm{ha}$.

Rakentamattomien alueiden kauppahintojen perusteella laskettu pellon arvo oli $147000 \mathrm{mk} /$ verohehtaari ja I luokan peltoa kohden laskettuna se olisi 191000 $\mathrm{mk} /$ peltohehtaari. Rakentamattomien alueiden kaupoissa pellosta oli maksettu $85 \%$ rakennetun pellon hinnasta paikkakunnalla.

Tuotantokustannusten mukaan pellon arvo oli $157000 \mathrm{mk}$ peltohehtaaria kohden, mikä on enemmän kuin lisämaasta paikkakunnalla verohehtaaria kohden maksettu hinta. Tuotantokustannuslaskelmassa käytetty viljelykelpoisen maan arvo, tie- ja viemärikustannusten sekä peruskalkitus- ja lannoituskustannusten osuus vaatisi kuitenkin yksityiskohtaisemman selvityksen, ennenkuin tuotantokustannuslaskelmien perusteita voitaisiin pitää luotettavina. 
KIRJALLISUUTTA:

(1) AAlto, V. 1960. Maan luovuttamisesta tiealueeksi johtuvien korvausten määrittämisessä huomioon otettavia seikkoja. Maanmittaus $35: 6-14$.

(2) Arola, J. 1957. Rakennusten arvioimisesta. Miten rakennan 1957: $79-89$.

(3) КоккоNen, P. 1940. Maan »käypä hinta» Nurmijärven kunnassa vuosina 1934-38. Maatal.tiet. aikak. $12: 98-141$.

(4) LARSSON, G. 1952. Undersökning rörande saluvärdets påverkan av olika fastighetsförhållanden. Kungl. landbr.akad. tidskr. $91: 330-350$.

(5) Мйкı, A. 1950. Viljelysmaiden kivisyydestä Suomessa v. 1950. Maatal.seur.keskusl. karujen maiden valiok.julk. $1: 1-12$.

(6) Virolainen, J. 1950. Maatalousmaan arvioimisesta ja arvosta Suomessa 1934-1938. Maatal. tiet.aikak. $72: 1-283$.

(7) Asetus uudis- ja kivenraivauspalkkioista No 333/1955.

(8) Laki kiinteän omaisuuden pakkolunastuksesta yleiseen tarpeeseen. Annettu 14 pv:nä heinäkuuta 1898.

(9) Maataloushallituksen maanviljelystaloudellisen tutkimustoimiston tiedonantomoniste No 6-8. $1959-1961$.

(10) Ohjeet maatalouskiinteistöjen verojyvitystä ja -luokitusta varten. Valtiovarainministeriön veroasiainosaston julk. 92 .

SUMMARY:

THE VALUE OF FIELD IN THE COMMUNE OF LIPERI IN 1956-1960

ViLjo RyYNÄNEN

Department of Agricultural Economics, University of Helsinki

The commune of Liperi is in East Finland, $0-45 \mathrm{~km}$ west of Joensuu. A railway and two heavilytrafficked roads run across the area. About 30 per cent of the total area is water. Field area accounts for 16 per cent of the total area. Many large lakes make the climate of the area, despite its northern location, relatively favourable for plant cultivation.

The value of field was determined on the basis of sales and production costs estimates.

The bases for the sales estimate are the prices paid in free transaction (not compulsory sale or transactions between relations). The investigation material comprised transactions on 7 farms and 11 unbuilt field areas. Table 1 shows some properties of the farms examined. The arable land and meadow areas are expressed in terms of tax-hectares. The tax-hectare is a unit employed in the tax assessment of agricultural land. It corresponds roughly to one hectare of medium quality field.

The price of field in the total price of the farm was established by personal visits to the farms sold, and on the spot appraisal of the arable land, meadow, forest and the buildings. The selling price was divided by the appraised value of the holding, and the appraised value of arable land and meadow was multiplied by the quotient thus obtained. The result gave the price paid for arable land and meadow. The results for each item of the transaction are given in Table 2.

The value of field including all buildings, farm buildings (excluding residential housing), and without buildings, calculated per tax-hectare, is shown in Table 3. The table also shows the sum paid for field areas without buildings.

Calculated on the basis of production costs, the value of field in the area of Liperi commune was $157000 \mathrm{marks} /$ hectare. This figure is $10000 \mathrm{marks} /$ hectare more than the price paid in transactions involving unbuilt areas. 